\title{
Alkali Pretreatment of Paper Mill Sludge to Enhance Biogas Production
}

\author{
R. Shreelavaniya ", G. Saravanapriya and T. Karuppayee \\ ICAR research centre on Bioconversion Technology, Sri Parasakthi College for Women, \\ Courtallam, Tenkasi District, Tamil Nadu, India \\ *Corresponding author
}

\section{A B S T R A C T}

\begin{tabular}{l} 
Ke y w o r d s \\
Paper mill sludge, \\
Anaerobic \\
digestion, Alkali \\
pretreatment, \\
Biogas production \\
\hline Article Info \\
Accepted: \\
07 January 2021 \\
Available Online: \\
10 February 2021
\end{tabular}

Introduction

Pulp and paper industry are one of the most polluting, energy and water intensive industries in the world. Produced pulp and paper mill sludge (PPMS) faces a major problem for handling and its management. An anaerobic digestion has become an alternative source. Anaerobic digestion (AD) of solid organic waste has gained increased attention as a means of producing energy-rich biogas, destructing pathogenic organisms and reducing problems associated with the disposal of organic waste. Paper mill sludge is produced in the mill's wastewater treatment process. An alternative is to use anaerobic digestion on the sludge and by doing so extract renewable energy in the form of biogas. Furthermore, the paper industries have some processes that currently require fossil fuels, for which biogas or pure methane could become a renewable fuel alternative and thus make the mills less dependent on fossil fuels.

Using paper mill sludge as a biogas substrate would promote the sustainable development of society, turn waste into raw material, and be in line with current bio-economic thinking. Pre-treatment can be used to reduce the necessary retention time to produce biogas. For example, certain processes shred the substrates to increase the surface area or use a 
thermal pre-treatment stage to significantly enhance the biogas output. The thermal treatment can also be used to reduce the pathogenic concentration in the digestate. The aim of pre-treatment of sludge is to lyse the cell structures, which benefits especially the first step of the methane production process, the hydrolysis. Anaerobic digestion is a process driven by bacteria in an oxygen-free environment. The process is divided into three steps-hydrolysis, fermentation and methane production - in which the macromolecules are cleaved, and acid, acetate and methane are formed. In industrial anaerobic digestion, the temperature is usually between $30-40{ }^{\circ} \mathrm{C}$ or $40-60^{\circ} \mathrm{C}$, depending on whether the bacterial culture is mesophilic or thermophilic. Mesophilic digestion is more stable and demands less added heat, whereas, thermophilic digestion is faster as increased temperature increase reaction rates. Possibly mesophilic digestion in combination with pretreatment could be a suitable compromise. Anaerobic digestion is most often considered to berate limited by the hydrolysis and cell lysis stages. Various sludge disintegration methods have been studied for pre-treatment purposes in order to increase the rate of methane production, including thermal, chemical, mechanical and biological methods. With paper mill sludge, increased methane yields under mesophilic conditions have been reported from alkali, microwave, hydrothermal and ultrasound pre-treatments (Wood, N et al., 2009, Saha, M et al., 2011).

The most studied chemical pre-treatment is the addition of sodium hydroxide $(\mathrm{NaOH})$. Other bases studied include potassium hydroxide $(\mathrm{KOH})$, magnesium hydroxide $\left(\mathrm{Mg}(\mathrm{OH})_{2}\right)$ and calcium hydroxide $\left(\mathrm{Ca}(\mathrm{OH})_{2}\right)_{\text {. Sodium hydroxide has been }}$ shown to have a very positive effect, often in combination with thermal pre-treatment, though high concentrations of $10 \mathrm{~g} \mathrm{NaOH} / \mathrm{L}$ can cause the formation of persistent compounds. An alkali pre-treatment process using sodium hydroxide solution showed an optimal concentration of $8 \mathrm{~g} \mathrm{NaOH} / 100 \mathrm{~g}$ TS sludge (total solids of the sludge) with a methane yield of $0.32 \mathrm{~m}^{3} / \mathrm{kg}$ VS removal (volatile solids removed by anaerobic digestion) which was $183 \%$ of the control (Lin, Y. Q., 2009). The disadvantages with sodium hydroxide are cost and environmental hazard. Calcium hydroxide, also known as lime, has a cost of only $6 \%$ of the price of lye and is easier to handle, which makes it interesting as a base pre-treatment method (Hu and Ragauskas, 2012). Acid pretreatment gives an increased solubility of the particles in the sludge, though acidic pretreatments may, however, produce compounds that can cause inhibition and/or be toxic to methane producing anaerobic microorganisms (Galbe and Zacchi, 2012). Alkali addition has been shown to increase solubilization of PPMS and improve biogas yield (Park et al., 2012).

This study aimed to analyze the potential to enhance biogas production from papermill sludge by the use of pretreatments and to find out the optimum percentage of substitution of pretreated paper mill sludge for maximum biogas production.

\section{Materials and Methods}

Paper mill sludge was collected from paper mill industry, which is located at $50 \mathrm{~km}$ distance from research station. Sludge is the solid residue formed during wastewater treatment (mixed with water). Disposal of solid organic waste (especially if it is wet) is expensive, whereas thermal destruction is both expensive and energy-demanding. Efforts have therefore been made to minimize the production of sludge by using advanced biological treatment processes. Two types of sludge materials are disposed off daily from the mill. One type of sludge contains $50 \%$ 
organic material and 50\% inorganic material. Other type of sludge contains $20 \%$ organic material and $80 \%$ inorganic material. Hence, the investigation was carried out using the first type (50:50) sludge.

Pretreatment disintegrate the floc structure of sludge and extract both intracellular and extracellular materials, which enhances the biogas production. Paper mill sludge was treated with sodium hydroxide, sodium bicarbonate, sodium hypo-chloride, calcium hydroxide and kept aside for 24 hours. The structure of the substrate remains unchanged except sodium hydroxide. Treatment with $0.5 \mathrm{~N}, 1 \mathrm{~N}, 1.5 \mathrm{~N}$ and $2 \mathrm{~N}$ sodium hydroxide caused changes in the structure of the paper mill sludge but the $\mathrm{pH}$ was above 9.6. This $\mathrm{pH} 9.6$ is not suitable for biogas production. There is a reduction in $\mathrm{pH}$ was observed when $0.01 \mathrm{~N}$ sodium hydroxide was used with paper mill sludge with cow dung. Therefore, $0.01 \mathrm{~N}$ sodium hydroxide can be used for paper mill sludge. This treated paper mill sludge when mixed with cow dung, the reduction in $\mathrm{pH}$ was well suitable for biogas production. Therefore, $0.01 \mathrm{~N}$ sodium hydroxide is used for alkali pretreatment.

\section{Laboratory experiment}

The paper mill sludge was collected from paper mill industry to determine the optimum percentage of paper mill sludge to be added with cow dung as feedstock. The laboratory batch fed fermentation setup was maintained in 5 liters Hofkins flask. The biochemical constituents of raw sludge and pretreated paper mill sludge were analyzed. Based on the chemical constituents of pretreated paper mill sludge, the experimental design was formulated to study the quantity of biogas production from paper mill sludge supplemented with cow dung as given in the Table1.
The laboratory experiments on batch fermentation were carried out in 5 litre Hofkin flasks with various proportions. The experimental setup was maintained for a period of 60 days. The batch 1 and 2 laboratory experiments were completed and the samples were taken for analysis. For each laboratory setup, the initial and final samples were drawn from the flask and the biochemical constituents such as $\mathrm{pH}$, volatile fatty acids, total solids, volatile solids, organic carbon, nitrogen, phosphorus, potassium, sodium were analyzed. Daily gas production was also recorded using water displacement method.

\section{Field experiment}

After completion of laboratory experiments, the field experiment was carried out in 2 cu.m. KVIC biogas plants located at ICAR research centre, Courtallam. The experimental design for field experiment is given in Table 2. Field experiment was conducted in $2 \mathrm{~m}^{3}$ KVIC biogas plant with various combinations of alkali pretreated paper mill sludge along with cow dung simultaneously control was monitored with only cow dung as shown in Fig. 1\&2. Paper mill sludge treated with 0.01 $\mathrm{N}$ sodium hydroxide is kept aside for 48 hours and after that this alkali treated paper mill sludge was mixed with cow dung in various combinations for biogas production and fed into the biogas plant.

Biochemical parameters of each field experiments, the slurry samples were taken weekly both at the initial and final stage of the experiment. Gas production was also recorded using gas flow meter with $75-100 \%$ replacement in the treatment plant. The samples of inlet and outlet of control plant and treatment plant were taken every week and the biochemical constituents such as $\mathrm{pH}$, volatile fatty acids, total solids, volatile solids, organic carbon, nitrogen, sodium, potassium 
and phosphorous were analyzed for each samples.

\section{Analytical methods}

The biochemical constituents of the raw paper mill sludge, initial and final slurry samples were analyzed. The $\mathrm{pH}$ of the slurry samples were estimated using systronic digital $\mathrm{pH}$ meter. The dry matter content of the samples was estimated by complete drying and successive weighing till constant weight is achieved (APHA, 1975). Nitrogen was estimated using micro Kjeldhal methods of Jackson (1958), Phosphorus was estimated by the method of Fiske and Subbarow (1925). Potassium and Sodium were measured by flame photometric method given in APHA (1975). Organic carbon was estimated by the method of Black et al (1965).The Cellulose and Hemi cellulose were determined by the method given by Updegraff (1969) and Horwitz (1960) respectively. Lignin content was estimated by the method given in DSTMACS Training Course Manual (1984). In field studies, daily gas production was recorded using gas flow meter. Statistical analysis was carried out according to the method given by Snedecor and Cochran (1967).

\section{Results and Discussion}

The biochemical constituents of raw paper mill sludge and pretreated paper mill sludge are given in Table3. The total solid and volatile solid content for raw paper mill sludge and pretreated papermill sludge were found to be $37.2 \%, 18.90 \%$ and $60.98 \%$, $50.47 \%$ respectively. According to Gijzen et al., 1990, the total solids of paper mill sludge was $39.8 \%$ and volatile solids was $42.6 \%$. These values are comparable with the results of biochemical composition of paper mill sludge in the present study.
As reported by Lin et al., 2013, the organic carbon and total nitrogen content in paper mill sludge was $34.75 \%$ and $1.12 \%$, which is nearly matched with the results of present analysis. As reported in literature, the range of $\mathrm{C}: \mathrm{N}$ ratio of $20: 1$ to $30: 1$ materials can be used as a substrate for biogas production. The $\mathrm{C}: \mathrm{N}$ ratio of paper mill sludge was found to be 21.43 and pretreated paper mill sludge was 21.09, which makes it suitable as a substitute for cow dung in biogas production.

\section{Laboratory experiments}

The biochemical constituents of pretreated paper mill sludge and cow dung slurry samples of initial and final samples are given in Table 4. The operational $\mathrm{pH}$ of the anaerobic digestion affects the digestive process. The fermentation microorganisms can function in the range of $4-8.5$ (Hwang et $a l ., 2004)$. The ideal $\mathrm{pH}$ range for anaerobic digestion has been reported as 6.8 - 7.4. (Igoni, 2003). The pH of the slurry samples before and after digestion of each batches were recorded. The $\mathrm{pH}$ of the initial slurry samples were in the range of $7.25-7.63$ and that of final slurry samples were $6.5-7.0$. In the initial phase of anaerobic digestion process, the production of Volatile fatty acids (VFA) decreases the $\mathrm{pH}$ of the slurry. But the reaction of $\mathrm{CO}_{2}$ which is soluble in water with hydroxide ion forming bicarbonate ions, so forming $\mathrm{HCO}_{3}$, tends to restore the neutrality of the process $\mathrm{pH}$. When rate of acid formation exceeds the rate of breakdown to methane, the process imbalance which results in $\mathrm{pH}$ decrease.

There is a reasonable reduction in total solids and volatile solid content of final slurry samples in all treatments (Table. 4). This reduction in the total solids and volatile solids at the final stage of experiment indicates the effective utilization of the substrate, which is reflected in the gas production. 
Table.1 Experimental Design for pretreated paper mill sludge with cow dung for biogas production

\begin{tabular}{|c|c|c|}
\hline S. No. & Setup & Proportions \\
\hline \multicolumn{3}{|r|}{ Batch 1} \\
\hline 1. & Control & Cow dung alone \\
\hline 2. & Treatment I & $25 \%$ Tr. Paper mill sludge $+75 \%$ cow dung \\
\hline 3. & Treatment II & $50 \%$ Tr. Paper mill sludge $+50 \%$ cow dung \\
\hline 4. & Treatment III & $75 \%$ Tr. Paper mill sludge $+25 \%$ cow dung \\
\hline 5. & Treatment IV & 100\% Tr. Paper mill sludge \\
\hline \multicolumn{3}{|r|}{ Batch 2} \\
\hline 1. & Control & Cow dung alone \\
\hline 2. & Treatment I & $25 \%$ Tr. Paper mill sludge $+75 \%$ cow dung \\
\hline 3. & Treatment II & $50 \%$ Tr. Paper mill sludge $+50 \%$ cow dung \\
\hline 4. & Treatment III & $75 \%$ Tr. Paper mill sludge $+25 \%$ cow dung \\
\hline 5. & Treatment IV & 100\% Tr. Paper mill sludge \\
\hline
\end{tabular}

Table.2 Experimental design for field experiments

\begin{tabular}{|c|l|l|}
\hline S. No. & \multicolumn{1}{|c|}{ Setup } & \multicolumn{1}{c|}{ Combination } \\
\hline $\mathbf{1 .}$ & Control & Cow dung alone \\
\hline $\mathbf{2 .}$ & Treatment I & 75\% Alkali *TrPaper mill sludge + 25\% cow dung \\
\hline $\mathbf{3 .}$ & Treatment II & $80 \%$ Alkali $*$ Tr Paper mill sludge + 20\% cow dung \\
\hline $\mathbf{4 .}$ & Treatment III & $90 \%$ Alkali $*$ Tr Paper mill sludge + 10\% cow dung \\
\hline $\mathbf{5 .}$ & Treatment IV & 100\% Alkali *Tr Paper mill sludge \\
\hline
\end{tabular}

Table.3 Biochemical composition of paper mill sludge (50:50) and pretreated paper mill sludge

\begin{tabular}{|c|l|c|c|}
\hline S.No. & Constituents & Raw paper mill sludge, $\%$ & Pretreated paper mill sludge, \\
$\mathbf{\%}$
\end{tabular}


Table.4 Effect of chemically treated paper mill sludge and cattle dung in various combinations on biochemical constituents of initial and final slurry samples

\begin{tabular}{|c|c|c|c|c|c|c|c|c|c|c|}
\hline S. No. & Treatments & pH & $\begin{array}{c}\text { VFA } \\
\text { mg/litre } \\
\text { as acetic } \\
\text { acid }\end{array}$ & $\begin{array}{c}\text { Total } \\
\text { Solids } \\
\%\end{array}$ & $\begin{array}{c}\text { Volatile } \\
\text { solids } \\
\%\end{array}$ & $\begin{array}{c}\text { Organic } \\
\text { Carbon } \\
\%\end{array}$ & $\begin{array}{c}\text { Nitrogen } \\
\%\end{array}$ & $\begin{array}{c}\text { Phospho- } \\
\text { rus } \\
\%\end{array}$ & $\begin{array}{c}\text { Potassium } \\
\%\end{array}$ & $\begin{array}{l}\text { Sodium } \\
\%\end{array}$ \\
\hline \multicolumn{11}{|l|}{ Initial } \\
\hline 1. & Cow dung alone & 7.25 & 312 & 10.01 & 79.04 & 31.5 & 1.47 & 1.044 & 1.41 & 2.78 \\
\hline 2. & $\begin{array}{l}25 \% \text { Tr. Paper mill sludge } \\
+75 \% \text { cow dung }\end{array}$ & 7.25 & 240 & 10.06 & 69.75 & 29.8 & 1.36 & 0.968 & 2.06 & 0.99 \\
\hline 3. & $\begin{array}{l}50 \% \text { Tr. Paper mill sludge } \\
+50 \% \text { cow dung }\end{array}$ & 7.30 & 197 & 10.03 & 63.69 & 28.5 & 1.21 & 0.584 & 2.39 & 1.43 \\
\hline 4. & $\begin{array}{l}75 \% \text { Tr. Paper mill sludge } \\
+25 \% \text { cow dung }\end{array}$ & 7.50 & 249 & 10.05 & 63.73 & 29.1 & 1.05 & 0.322 & 2.57 & 1.74 \\
\hline 5. & $\begin{array}{l}\text { 100\% Tr. Paper mill } \\
\text { sludge }\end{array}$ & 7.63 & 257 & 10.09 & 65.93 & 28.20 & 1.01 & 0.256 & 2.73 & 1.99 \\
\hline \multicolumn{11}{|l|}{ Final } \\
\hline 1. & Cow dung alone & 7.0 & 720 & 6.70 & 69.07 & 28.5 & 1.05 & 1.336 & 1.16 & 0.88 \\
\hline 2. & $\begin{array}{l}25 \% \text { Tr. Paper mill sludge } \\
+75 \% \text { cow dung }\end{array}$ & 6.58 & 960 & 5.18 & 63.10 & 26.7 & 0.78 & 1.244 & 1.34 & 1.35 \\
\hline 3. & $\begin{array}{l}50 \% \text { Tr. Paper mill sludge } \\
+50 \% \text { cow dung }\end{array}$ & 6.50 & 744 & 5.41 & 59.8 & 25.8 & 0.74 & 0.872 & 2.26 & 1.28 \\
\hline 4. & $\begin{array}{l}75 \% \text { Tr. Paper mill sludge } \\
+25 \% \text { cow dung }\end{array}$ & 6.78 & 888 & 5.82 & 56.63 & 24.6 & 0.66 & 0.444 & 2.46 & 1.67 \\
\hline 5. & $\begin{array}{l}100 \% \text { Tr. Paper mill } \\
\text { sludge }\end{array}$ & 7.0 & 936 & 6.65 & 57.94 & 22.50 & 0.54 & 0.288 & 2.49 & 1.78 \\
\hline
\end{tabular}

Table.5 Effect of chemically treated papermill sludge mixed with cow dung in various proportions on biogas production

\begin{tabular}{|c|c|c|c|c|c|}
\hline \multirow{2}{*}{$\begin{array}{l}\text { S. } \\
\text { No. }\end{array}$} & \multirow[t]{2}{*}{ Treatments } & \multirow{2}{*}{$\begin{array}{c}\text { Total } \\
\text { Solids, \% }\end{array}$} & \multirow{2}{*}{$\begin{array}{c}\text { Gas Production, } \\
\text { litre/kg of dry } \\
\text { matter }\end{array}$} & \multicolumn{2}{|c|}{ Temperature, ${ }^{\circ} \mathrm{C}$} \\
\hline & & & & Min. & Max. \\
\hline 1. & Cow dung alone & 10.01 & 187.54 & 28 & 31 \\
\hline 2. & $\begin{array}{l}25 \% \text { Tr. Paper mill sludge }+ \\
75 \% \text { cow dung }\end{array}$ & 10.06 & 190.63 & 28 & 31 \\
\hline 3. & $\begin{array}{l}50 \% \text { Tr. Paper mill sludge }+ \\
50 \% \text { cow dung }\end{array}$ & 10.03 & 195.44 & 28 & 31 \\
\hline 4. & $\begin{array}{l}75 \% \text { Tr. Paper mill sludge }+ \\
25 \% \text { cow dung }\end{array}$ & 10.05 & 197.36 & 28 & 31 \\
\hline 5. & $100 \%$ Tr. Paper mill sludge & 10.09 & 178.58 & 28 & 31 \\
\hline
\end{tabular}


Table.6 Effect of chemically treated paper mill sludge mixed with cow dung in various proportions on weekly gas production - Laboratory study

\begin{tabular}{|c|c|c|c|c|c|c|}
\hline S.No. & Week & $\begin{array}{c}\text { Cow dung } \\
\text { alone }\end{array}$ & $\begin{array}{c}\mathbf{2 5 \%} \text { Tr. } \\
\text { Paper mill } \\
\text { sludge }+ \\
\mathbf{7 5 \%} \text { cow } \\
\text { dung }\end{array}$ & $\begin{array}{c}\mathbf{5 0 \%} \text { Tr. } \\
\text { Paper mill } \\
\text { sludge }+ \\
\mathbf{5 0 \%} \\
\text { dung }\end{array}$ & $\begin{array}{c}\text { 75\% Tr. } \\
\text { Paper mill } \\
\text { sludge + } \\
\mathbf{2 5 \%} \text { cow } \\
\text { dung }\end{array}$ & $\begin{array}{c}\text { 100\% Tr. } \\
\text { Paper mill } \\
\text { sludge }\end{array}$ \\
\hline 1. & Week I & 6820 & 6080 & 7135 & 6620 & 7251 \\
\hline 2. & Week II & 9120 & 9738 & 9535 & 9470 & 8527 \\
\hline 3. & Week III & 8620 & 10318 & 10710 & 11015 & 9349 \\
\hline $\mathbf{4 .}$ & Week IV & 10830 & 10496 & 12770 & 12295 & 10649 \\
\hline 5. & Week V & 9520 & 9178 & 8930 & 8905 & 8327 \\
\hline 6. & Week VI & 9105 & 9756 & 8300 & 7745 & 8731 \\
\hline 7. & Week VII & 9095 & 9658 & 9470 & 10275 & 8987 \\
\hline 8. & Week VIII & 11980 & 11486 & 11560 & 13015 & 10249 \\
\hline & Total & 75090 & 76710 & 78410 & 79340 & 72070 \\
\hline Weekly average & 9386.25 & 9588.75 & 9801.75 & 9917.5 & 9008.75 \\
\hline
\end{tabular}

Table.7 Effect of pretreated paper mill sludge and cattle dung in various combination on biochemical composition of biogas slurry - field experiments

\begin{tabular}{|c|c|c|c|c|c|c|c|c|c|c|c|c|}
\hline $\begin{array}{l}\text { S. } \\
\text { No. }\end{array}$ & Treat & ents & pH & $\begin{array}{c}\text { VFA } \\
\text { mg/litre } \\
\text { as acetic } \\
\text { acid }\end{array}$ & $\begin{array}{c}\text { Total } \\
\text { Solids } \\
\%\end{array}$ & $\begin{array}{c}\text { Volatile } \\
\text { solids } \\
\%\end{array}$ & $\begin{array}{c}\text { Organic } \\
\text { Carbon } \\
\%\end{array}$ & $\begin{array}{c}\text { Nitrogen } \\
\%\end{array}$ & $\begin{array}{c}\text { Phospho } \\
\text { rus } \\
\%\end{array}$ & $\begin{array}{c}\text { Potassium } \\
\%\end{array}$ & $\begin{array}{c}\text { Sodium } \\
\%\end{array}$ & $\begin{array}{c}\text { Gas } \\
\text { output } \\
\text { litre/kg } \\
\text { DM } \\
\end{array}$ \\
\hline \multirow[t]{4}{*}{1.} & \multirow[t]{2}{*}{ Control } & Inlet & 7.38 & 242 & 10.68 & 70.30 & 30.10 & 2.40 & 0.191 & 0.29 & 3.19 & \multirow[t]{2}{*}{209} \\
\hline & & Outlet & 7.27 & 694 & 7.80 & 52.80 & 26.85 & 3.15 & 0.615 & 0.20 & 0.67 & \\
\hline & \multirow{2}{*}{$\begin{array}{l}75 \% \text { PMS + } \\
25 \% \text { cow } \\
\text { dung }\end{array}$} & Inlet & 7.20 & 276 & 9.89 & 74.48 & 29.20 & 1.61 & 0.265 & 0.37 & 0.70 & \multirow[t]{2}{*}{232} \\
\hline & & Outlet & 7.06 & 757 & 6.92 & 54.76 & 25.10 & 2.59 & 0.369 & 0.20 & 0.63 & \\
\hline \multirow[t]{4}{*}{2.} & \multirow[t]{2}{*}{ Control } & Inlet & 7.23 & 221 & 10.28 & 63.61 & 30.40 & 2.71 & 0.401 & 0.08 & 0.36 & \multirow[t]{2}{*}{216} \\
\hline & & Outlet & 6.96 & 716 & 7.83 & 58.58 & 27.90 & 3.08 & 0.508 & 0.05 & 0.36 & \\
\hline & \multirow{2}{*}{$\begin{array}{l}80 \% \text { PMS + } \\
20 \% \text { cow } \\
\text { dung }\end{array}$} & Inlet & 7.30 & 172 & 10.59 & 64.52 & 30.90 & 2.10 & 0.376 & 0.06 & 0.29 & \multirow[t]{2}{*}{246} \\
\hline & & Outlet & 7.10 & 854 & 6.29 & 52.48 & 26.20 & 2.67 & 0.348 & 0.04 & 0.31 & \\
\hline \multirow[t]{4}{*}{3.} & \multirow[t]{2}{*}{ Control } & Inlet & 7.23 & 264 & 9.96 & 71.53 & 29.40 & 1.49 & 0.667 & 0.10 & 0.50 & \multirow[t]{2}{*}{227} \\
\hline & & Outlet & 6.87 & 842 & 6.38 & 56.98 & 26.50 & 1.86 & 0.840 & 0.09 & 0.38 & \\
\hline & \multirow{2}{*}{$\begin{array}{l}90 \% \text { PMS + } \\
10 \% \text { cow } \\
\text { dung }\end{array}$} & Inlet & 7.19 & 248 & 9.69 & 61.02 & 25.20 & 1.43 & 0.803 & 0.11 & 0.43 & \multirow[t]{2}{*}{252} \\
\hline & & Outlet & 6.92 & 954 & 6.18 & 50.11 & 21.40 & 1.78 & 0.741 & 0.08 & 0.44 & \\
\hline \multirow[t]{4}{*}{4.} & \multirow[t]{2}{*}{ Control } & Inlet & 7.14 & 228 & 10.58 & 62.65 & 26.40 & 1.90 & 0.072 & 0.08 & 0.61 & \multirow[t]{2}{*}{223} \\
\hline & & Outlet & 6.86 & 982 & 7.47 & 54.02 & 22.70 & 2.20 & 0.061 & 0.07 & 0.44 & \\
\hline & \multirow{2}{*}{$\begin{array}{l}100 \% \text { PMS } \\
+0 \% \text { cow } \\
\text { dung }\end{array}$} & Inlet & 7.21 & 184 & 10.05 & 72.20 & 27.90 & 1.86 & 0.045 & 0.04 & 0.71 & \multirow[t]{2}{*}{213} \\
\hline & & Outlet & 6.91 & 994 & 6.97 & 50.31 & 22.20 & 2.04 & 0.044 & 0.05 & 0.49 & \\
\hline
\end{tabular}


Table.8 Effect of chemically treated papermill sludge mixed with cow dung in various proportions on biogas production - field experiments

\begin{tabular}{|c|c|c|c|c|c|}
\hline \multirow[t]{2}{*}{ S. No. } & \multirow[t]{2}{*}{ Treatments } & \multirow{2}{*}{$\begin{array}{c}\text { Total } \\
\text { Solids, \% }\end{array}$} & \multirow{2}{*}{$\begin{array}{c}\text { Gas } \\
\text { Production, } \\
\text { litre/kg of dry } \\
\text { matter }\end{array}$} & \multicolumn{2}{|c|}{ Temperature, ${ }^{\circ} \mathrm{C}$} \\
\hline & & & & Min. & Max. \\
\hline \multirow[t]{2}{*}{1.} & Control & 10.68 & 209 & 27 & 32 \\
\hline & $75 \%$ Tr. Paper mill sludge $+25 \%$ cow dung & 9.89 & 232 & 27 & 32 \\
\hline \multirow[t]{2}{*}{2.} & Control & 10.28 & 216 & 28 & 31 \\
\hline & $80 \%$ Tr. Paper mill sludge $+20 \%$ cow dung & 10.59 & 246 & 28 & 31 \\
\hline \multirow[t]{2}{*}{3.} & Control & 9.96 & 227 & 28 & 30 \\
\hline & $90 \%$ Tr. Paper mill sludge $+10 \%$ cow dung & 9.69 & 252 & 28 & 30 \\
\hline \multirow[t]{2}{*}{4.} & Control & 10.58 & 223 & 28 & 30 \\
\hline & $100 \%$ Tr. Paper mill sludge $+0 \%$ cow dung & 10.05 & 213 & 28 & 30 \\
\hline
\end{tabular}

Fig.1 Feeding of alkali pretreated Paper Mill Sludge into Biogas plant

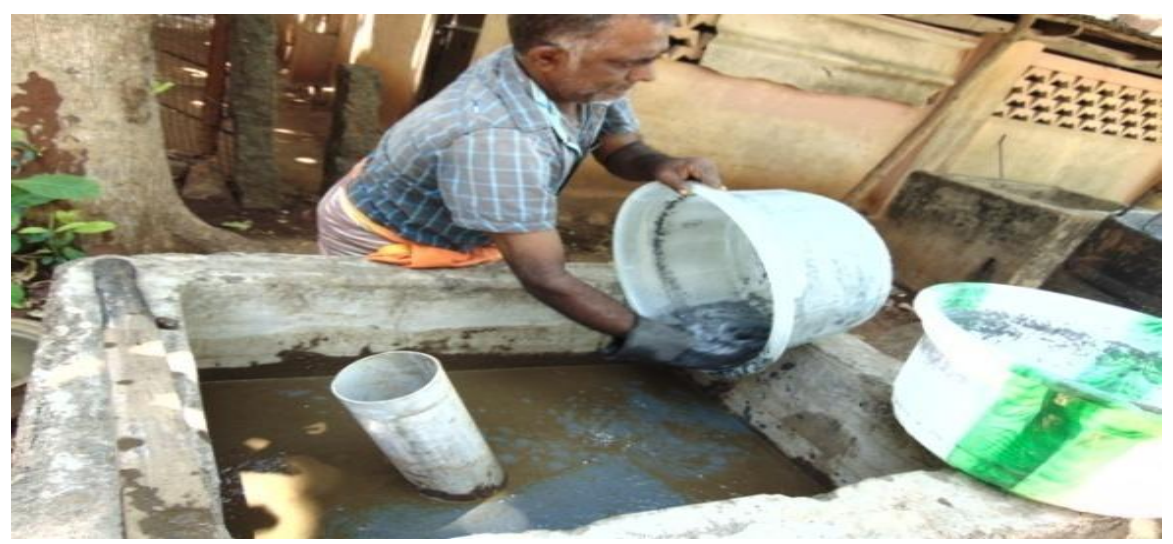

Fig.2 Monitoring of biogas production in $2 \mathrm{cu} . \mathrm{m}$ pretreated paper mill sludge biogas plant

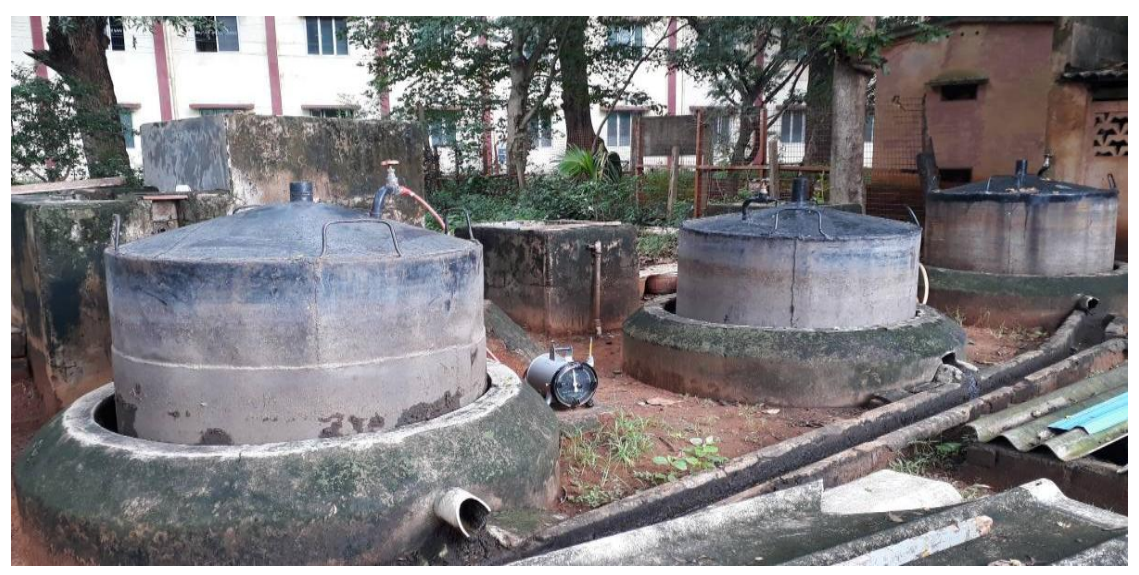


Fig.3 Gas production per kg of dry matter for various percentage of pretreated paper mill sludge - Lab study

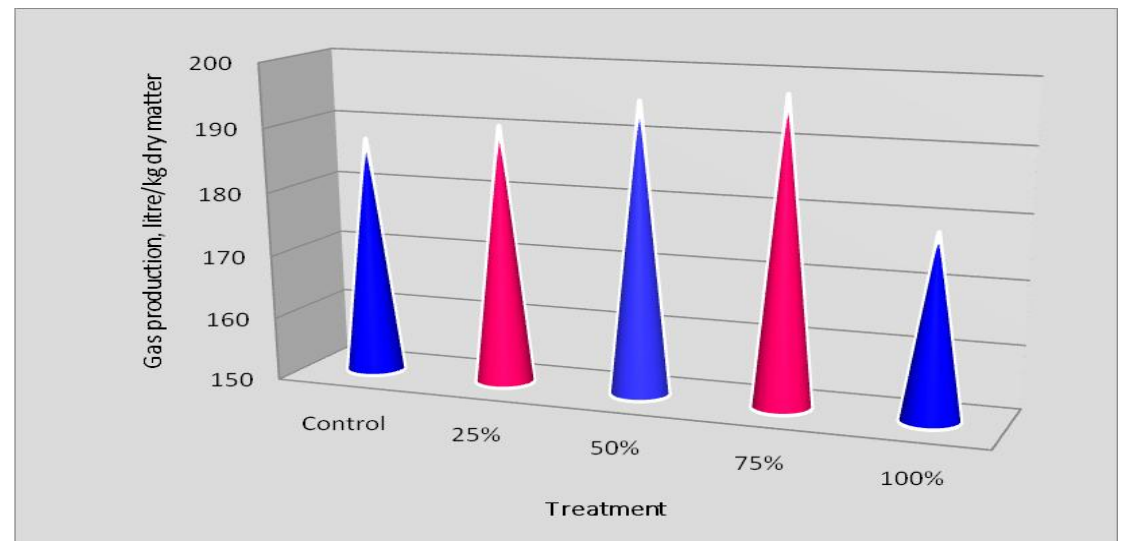

Fig.4 Total gas production for various percentage of pretreated paper mill sludge substitution Lab study

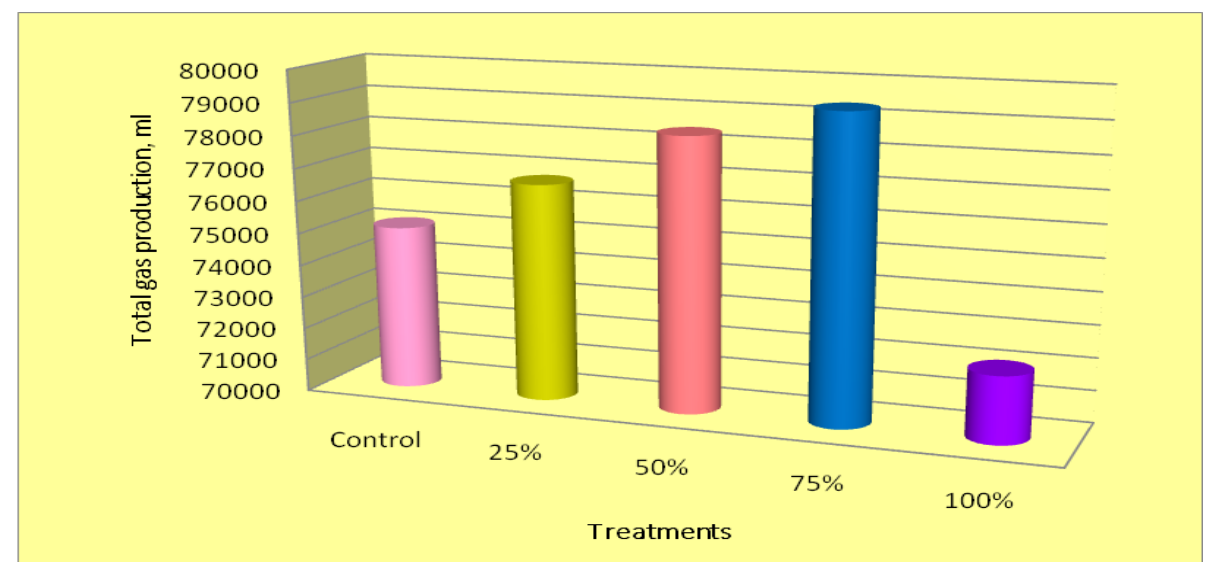

Fig.5 Weekly gas production for various percentage of pretreated paper mill sludge substitution - Lab study

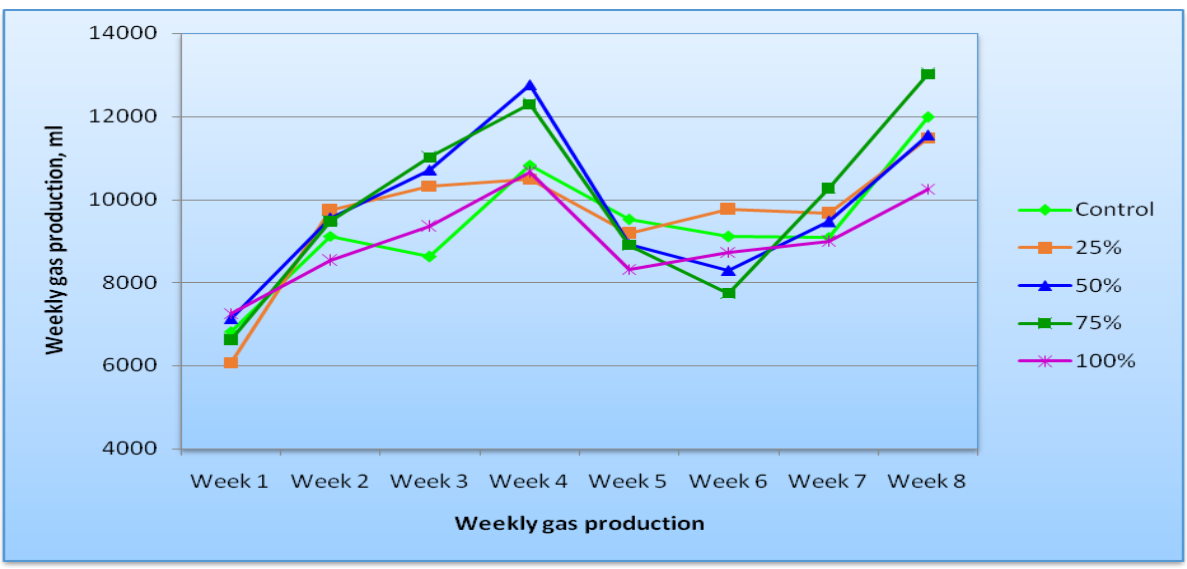


Fig.6 Total gas production for various percentage of pretreated paper mill slugde substitution Field experiments

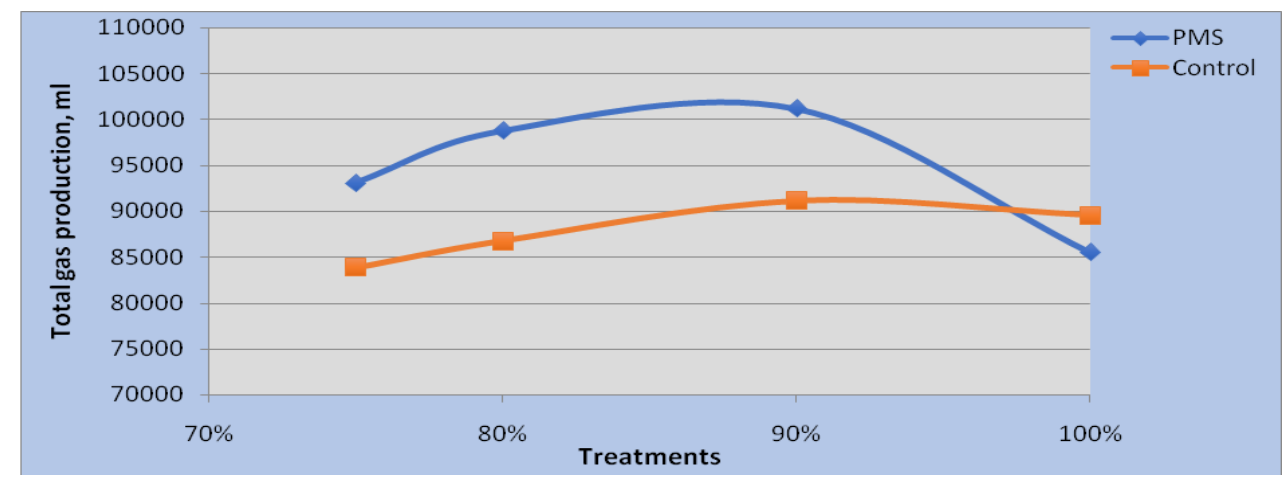

Fig.7 Gas production per kg of dry matter for various percentage of pretreated paper mill sludge - Field experiments

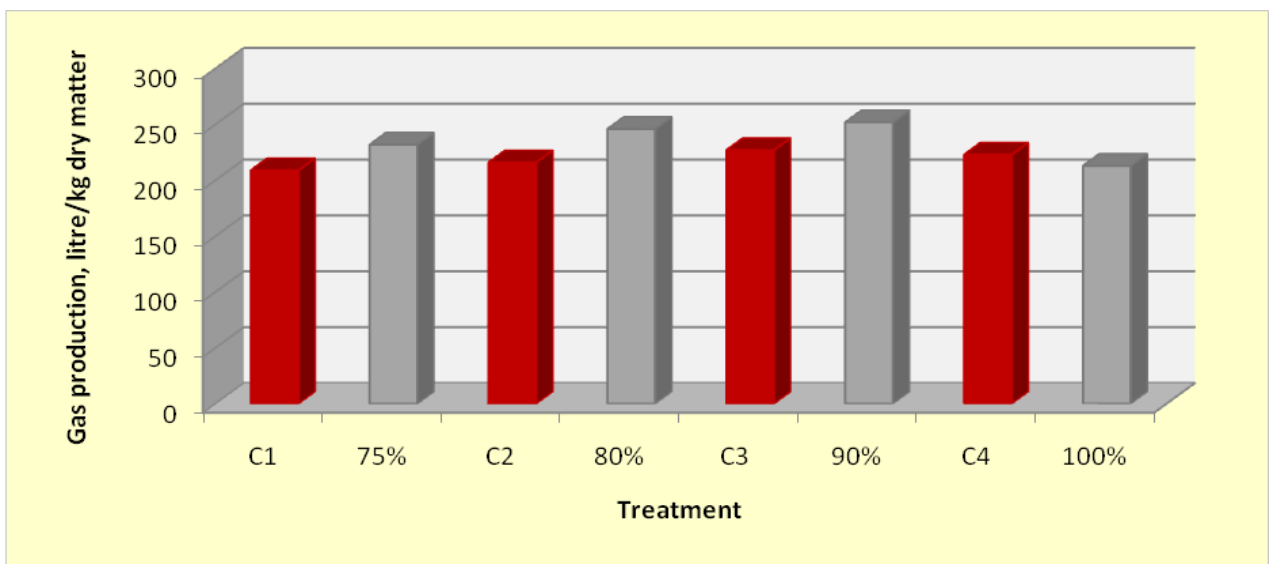

The organic carbon of inlet slurry is much higher than outlet slurry in all treatments, which showed that the carbon content was converted as $\mathrm{CO}_{2}$ during anaerobic digestion process. The nitrogen content of inlet and outlet slurry of control was higher than the other treatments. In case of phosphorus, potassium and sodium, the outlet slurry has lower value than inlet samples in all treatments except phosphorous.

The digestion period for all the treatments was given as 60 days. Dailybiogas production, total biogas production and weekly biogas production were recorded. The gas production per $\mathrm{kg}$ of total solid content was estimated for various treatments of pretreated paper mill sludge substitution and is given in Table 5. The gas production for $25 \%, 50 \%, 75 \%$ and $100 \%$ pretreated paper mill sludge was 190.63 litre $/ \mathrm{kg}$ of dry matter, 195.44 litre/kg of dry matter, 197.36 litre $/ \mathrm{kg}$ of dry matter and 178.58 litre/kg of dry matter respectively whereas in control it is 187.54 litre/kg of dry matter. Gas production per $\mathrm{kg}$ of dry matter for various percentage of pre treated paper mill sludge in given in Fig. 3. From the figure, the maximum gas production was observed in $75 \%$ pretreated paper mill sludge substitution. The weekly gas production for various percentage of pretreated paper mill sludge is given in Table. 6. 
The total gas production and weekly gas production throughout the period of anaerobic digestion is given in Figure 4 and 5. It was observed that the minimum and maximum total gas production was $75,090 \mathrm{ml}$ and $79,340 \mathrm{ml}$ respectively. The maximum total gas production was observed in $75 \%$ pretreated paper mill sludge substitution. However, there was not much variation from $75 \%$ to $100 \%$. It indicates that the paper mill sludge could replace cow dung feeding upto $100 \%$ supplementation. Therefore, cattle dung feeding could be completely replaced by pretreated paper mill sludge for biomethanation process.

Based on the laboratory experiments, the alkali pretreated paper mill sludge can be effectively utilized for biogas production upto $75 \%$ replacement. It was observed that the minimum and maximum total gas production was $75,090 \mathrm{ml}$ and $79,340 \mathrm{ml}$ respectively. The maximum total gas production was observed in $75 \%$ pretreated paper mill sludge substitution. However, there was not much variation from $75 \%$ to $100 \%$. It indicates that the paper mill sludge could replace cow dung feeding upto $100 \%$ supplementation. Hence, the field experiment was conducted from $75 \%$ to $100 \%$ substitution of pretreated paper mill sludge.

\section{Field experiments}

In field experiments, the biochemical constituents of slurry samples before and after digestion for control and treatment plant is given in Table. 7. The $\mathrm{pH}$ of the anaerobic digestion affects the digestive process. The fermentation microorganisms can function in the range of 4 - 8.5 (Hwang et al., 2004). The ideal $\mathrm{pH}$ range for anaerobic digestion has been reported as 6.8 - 7.4 (Igoni, 2008). The $\mathrm{pH}$ of the slurry samples before and after digestion of each treatment was recorded. The $\mathrm{pH}$ of the initial slurry samples was in the range of $7.14-7.38$ and that of final slurry samples were6.86 - 7.27. In the initial phase of anaerobic digestion process, the production of Volatile fatty acids (VFA) decreases the $\mathrm{pH}$ of the slurry. But the reaction of $\mathrm{CO}_{2}$ which is soluble in water with hydroxide ion forming bicarbonate ions, so forming $\mathrm{HCO}_{3}$, tends to restore the neutrality of the process $\mathrm{pH}$. When rate of acid formation exceeds the rate of breakdown to methane, the process imbalance which results in $\mathrm{pH}$ decrease.

There is a reasonable reduction in total solids and volatile solid content of final slurry samples in all treatments. The total solids of outlet slurry were reduced because of the degradation of solid content during anaerobic digestion. The organic carbon of inlet slurry is much higher than outlet slurry which ranges from 25.20 to $30.90 \%$ in inlet slurry to 21.40 to $27.90 \%$ in outlet slurry of all treatments, which showed that the carbon content was converted as $\mathrm{CO}_{2}$ during anaerobic digestion process. Similar results were obtained by Lin, Y. Q., 2009. The nitrogen content is higher in outlet slurry samples of both control and treatment plant. The nitrogen content ranges from 1.43-3.15\% of all treatment. In case of phosphorus, the outlet slurry has higher value than inlet samples.

Gas production was also recorded using gas flow meter. Total biogas production, and average biogas production were calculated and recorded. The gas production per $\mathrm{kg}$ of total solid content was estimated for various treatments of paper mill sludge substitution in field experiments and is given in Table 8.

The total gas production throughout the period of anaerobic digestion for pretreated paper mill sludge substitution from $75 \%$ $100 \%$ and control are given in Fig. 6. The gas production for treatment plant is in the range of 213.0 to 252.0 litre $/ \mathrm{kg}$ of dry matter whereas in control plant it is $209-227$ 
litre/kg of dry matter which is shown in Fig. 7. The gas production was observed to be 232 litre $/ \mathrm{kg}$ of dry matter for $75 \%$ alkali pretreated paper mill sludge, 246 litre/kg of dry matter for $80 \%$ alkali pretreated paper mill sludge, 252 litre/kg of dry matter for $90 \%$ alkali pretreated paper mill sludge and 213 litre/kg of dry matter for $100 \%$ alkali pretreated paper mill sludge.

Hence, the maximum gas production of 252 liter $/ \mathrm{kg}$ dry matter was recorded in $90 \%$ alkali pretreated paper mill sludge substitution whereas in control it was 227 litre $/ \mathrm{kg}$ of dry matter. Based on the studies conducted earlier for biogas production using untreated paper mill sludge, it was observed that the maximum gas production was recorded in $60 \%$ paper mill sludge and it could replace $60 \%$ cow dung substitution. Based on this study, it clearly indicates that alkali/ $\mathrm{NaOH}$ pretreatment enhance the biogas production and effectively utilized the paper mill sludge upto $90 \%$ replacement from $60 \%$ (Untreated PMS), which shows that alkali pretreatment could be an effective method for improving methane yield in paper mill sludge.

In conclusion based on the laboratory experiments, the alkali pretreated paper mill sludge can be effectively utilized for biogas production up to $75 \%$ replacement. However, there was not much variation from $75 \%$ to $100 \%$. It indicates that the paper mill sludge could replace cow dung feeding upto $100 \%$ supplementation.

To find out the correct proportion of the pretreated paper mill sludge from $75 \%$ $100 \%$, field experiment was conducted and the maximum gas production was recorded in 90\% alkali pretreated paper mill sludge substitution. Based on this study, it clearly indicates that alkali/ $\mathrm{NaOH}$ pretreatment enhances the biogas production and effectively utilized the paper mill sludge upto $90 \%$ replacement.

\section{Acknowledgement}

Authors would like to thank ICAR - Central Institute of Agricultural Engineering, Bhopal scheme on AICRP on Energy in Agriculture and Agro-based industries for providing sufficient funds to carry out the research work successfully.

\section{References}

American Public Health Association (APHA) (1975). Standard methods for the examination of water and waste water. 15th Ed. Washington. D.C.

Black C.A., Evans, D.D., White, J.L. Engminger, L.E. and Clark, F.E. (1965). Methods of soil analysis Part - 2 . Chemical and Microbiological properties, American Society of Agronomy, Academic Press, New York, 1374 - 1376.

DST-MACS Training Course Manual (1984). Dept of Microbiology, Maharashtra association for the cultivation of science, law college road, Pune, 411004, India.

Fiske, C.M. and Subbarow, V. (1925). The colorimetric determination of phosphorus, J. biol.chem.66, 375 - 40.

Galbe, M.; Zacchi, G. (2012). Pretreatment: The Key to Efficient Utilization of Lignocellulosic Materials. Biomass and Bioenergy, 46, 70-78.

Gijzen, H. J., Derikx, P. J. L., and Vogels, G. D. (1990). Application of Rumen Microorganisms for a High sRate Anaerobic Digestion of Paper mill Sludge, Biological wastes. 32, 169-179.

Horwitz W. (1960). Official methods of analysis of AOAC, Washington. D.C., U.S.A.

Hu, F.; Ragauskas, A. (2012). Pretreatment and Lignocellulosic Chemistry. Bioenergy Research, 5(4), 1043-1066.

Hwang, M. H., Jang, N.J., Hyum, S. H., and Kim, I.S. (2004). Anaerobic bio- 
hydrogen production from ethanol fermentation: the role of $\mathrm{pH}, \quad \mathrm{J}$. Biotechnol. 111, 297 - 309.

Igoni, A. H., Ayotamuno, M. J., Eze, C. L., and Ogaji, S. O. T. (2008). Applied Designs of anaerobic digesters for producing biogas from municipal solidwaste, Applied Energy 85, 430-438. doi:10.1016/j.apenergy.2007.07.013

Jackson. M.L. (1958) Soil Chemical analysis, Prentice Hall of India Pvt. Ltd., New Delhi. 187 - 190.

Lin, Y. Q. (2009). Alkali Pretreatment Enhances Biogas Production in the Anaerobic Digestion of Pulp and Paper Sludge. Journal of Hazardous Materials, 170(1), 366-373.

Lin, Y., Wu, S., and Wang, D. (2013). Hydrogen-methane production from pulp and paper sludge and food waste by mesophilic - thermophilic anaerobic co-digestion. International Journal of Hydrogen Energy, 38(35), 1505515062.

doi:10.1016/j.ijhydene.2012.01.051
Park, N.D., Helle, S.S., Thring, R.W. 2012. Combined alkaline and ultrasound pretreatment of thickened pulp mill waste activated sludge for improved anaerobic digestion. Biomass and Bioenergy, 46, 750-756.

Saha, M.; Eskicioglu, C.; Marin, J. (2011). Microwave, Ultrasonic and Chemomechanical Pretreatments for Enhancing Methane Potential of Pulp Mill Wastewater Treatment Sludge. Bioresource Technology, 102(17), 7815-7826.

Snedecor, G.W., and Cocharan, W.G. (1967). Statistical methods, Lowa State University Press, Lowa, USA.

Updegraff, D.M. (1969). Semimicro determination of cellulose in biological materials. Anal. Biochem.32:420-424

Wood, N.; Tran, H.; Master, E. (2009). Pretreatment of Pulp Mill Secondary Sludge for High-Rate Anaerobic Conversion to Biogas. Bioresource Technology, 100(23), 5729-5735.

\section{How to cite this article:}

Shreelavaniya, R., G. Saravanapriya and Karuppayee, T. 2021. Alkali Pretreatment of Paper Mill Sludge to Enhance Biogas Production. Int.J.Curr.Microbiol.App.Sci. 10(02): 854-866. doi: https://doi.org/10.20546/ijcmas.2021.1002.101 